\title{
The effects of sGnRHa implants on Piaractus mesopotamicus female breeders. An approach addressed to aquaculture
}

\author{
Rafael Yutaka Kuradomi ${ }^{1}$. Fausto Foresti $^{1,2}$. \\ Sergio Ricardo Batlouni ${ }^{1}$
}

Received: 31 March 2017 / Accepted: 13 August 2017 / Published online: 21 August 2017

(C) Springer International Publishing AG 2017

\begin{abstract}
In this study, we evaluated the potential use of sGnRHa slow-release implants (150 $\mathrm{gg}$ - Ovaplant $($ ) for promoting an increased number of suitable Piaractus mesopotamicus females for induced spawning in a predictable period. To that, $f s h b, l h b$, and $g h$ gene expression, ovarian stereological evaluation and gonadal steroid concentrations were compared between treated and control females $(n=18)$ at 21, 35, and 115 days after sGnRHa implantation (DAI). The major differences between groups were observed at $35 \mathrm{DAI}$, when $l h b$ and $f s h b$ were, respectively, up and downregulated for treated females compared to the controls, and the frequency of treated females in an advanced maturation class was higher (60\%) than the controls (20\%). Especially for promoting a significant change in the gonadotrophins gene expression levels, we demonstrated for the first time that sGnRHa slow-release implants has potential to be used to manipulate the reproductive cycle increasing the number of suitable Piaractus mesopotamicus females for induced spawning in a predictable period. However, a definitive protocol still depends on more studies involving a greater number of treatments and replicates.
\end{abstract}

Keywords Pacu $\cdot$ Synchronization $\cdot$ Ovarian maturation $\cdot \mathrm{sGnRHa} \cdot$ Implants

\section{Introduction}

Pacu (Piaractus mesopotamicus) is a neotropical omnivorous characiform fish (Moro et al. 2013), which was the sixth most produced fish species in Brazil with 14.600T in 2014 (IBGE 2015). The

Sergio Ricardo Batlouni

batlouni@ caunesp.unesp.br

1 Centro de Aquicultura da UNESP-CAUNESP, Universidade Estadual Paulista-UNESP, Via de Acesso Prof. Paulo Donato Castellane, S/N, Jaboticabal, SP 14884-900, Brazil

2 Departamento de Morfologia, Instituto de Biociências, Universidade Estadual Paulista-UNESP, Distrito de Rubião Júnior, S/N, Botucatu, SP 18618-970, Brazil 
consolidation of this species in national and international aquaculture is due to favorable zootechnical characteristics, such as its rustic trait and fast growth under a variety of conditions (Gelman et al. 2004). However, despite the hormonal induction technique that has been used for decades, irregularities and deficiencies are still very common in the fry production of this species, especially in relation to unpredictable spawning success due to unsuccessful ovulation (CriscuoloUrbinati et al. 2012).

When kept in captivity, ovarian and testicular maturation takes place, reaching the more advanced stages of maturation between October and January (Lima et al. 1991; Romagosa et al. 1993). This fish is a total spawner species with group-synchronous oocyte development; hormonal stimulation is required for spawning in captivity (Criscuolo-Urbinati et al. 2012; Kuradomi et al. 2016). The most common method used for induced spawning is the application of crude carp pituitary extract (CPE) [two doses $(0.6$ and $5.4 \mathrm{mg} / \mathrm{kg}$ with a $24-\mathrm{h}$ interval between the doses)], but higher ovulation rates are achieved if a dose of synthetic prostaglan$\operatorname{din} \mathrm{F}$ ( $2 \mathrm{~mL}$ Ciosin ${ }^{\circledR}$ containing $0.25 \mathrm{mg} / \mathrm{mL}$ cloprostenol) is given at the time of the second CPE dose (Criscuolo-Urbinati et al. 2012). Concerning the use of synthetic products, in the 1980s, Carolsfeld and collaborators (1988a) showed that [D-Ala' des-Gly"] LHRH ethylamide analogue $(100 \mu \mathrm{g} / \mathrm{kg}$ in single dose) provoked final maturation and ovulation in this species. However, the use of LHRHa or other synthetic products was not continued due to inconsistent results obtained in later studies with pacu (Paulino et al. 2011) as well as for other South American reophilic species (Carneiro and Mikos, 2008; Acuña and Rangel 2009; Paulino et al. 2011; Pereira et al. 2017).

Among the many causes of unpredictable spawning (see review by Zohar and Mylonas 2001; Mylonas et al. 2010), we draw attention to the existence of intense heterogeneity in the distribution of ovarian maturation classes during the breeding season for pacu. First, this situation requires excessive management to obtain breeders suitable for induced spawning (in advanced maturation) among many other reproductive classes, which often impairs fish welfare, inhibiting reproduction (Campbell et al. 1992, 1994; Brooks et al. 1997; Bobe and Labbe 2010; Schreck 2010). Furthermore, this heterogeneity decreases the accuracy of selecting suitable females due to the imprecise methods employed by pacu fish farmers. Oftentimes, females considered suitable, with the softest bulging abdomens and hemorrhagic papillae, do not ovulate when subjected to conventional hormonal treatments, possibly because external assessments are not $100 \%$ reliable in selecting suitable females for spawning (Zohar 1989). Thus, the ability to ensure a higher frequency of suitable females at a predictable time is important for avoiding excessive handling and enabling a predictable spawning in this species.

In this regard, GnRH implants might be useful in producing a core group to trigger mass spawning (Carolsfeld et al. 1988b). Therefore, in combination with other hormones or alone, GnRHa slow-release implants have been applied successfully in some species of teleosts, such as Chanos chanos (Lee et al. 1986), Mugil cephalus (Aizen et al. 2005), and Pagrus major (Kumakura et al. 2003). In this context, these implants were used to anticipate the spawning period in milkfish, C. chanos (Lee et al. 1986), to intensify the vitellogenic process in gray mullet, M. cephalus (Aizen et al. 2005), and to induce vitellogenesis and spawning in prepubertal females of the red seabream, P. major (Kumakura et al. 2003). The effects of GnRHa implants on teleost ovarian maturation are preceded by changes in various levels of the hypothalamic-pituitary-gonadal axis, and growth hormone (Gh). Moreover, GnRH may also act on the synthesis and release of Gh, which can be considered as a "co-gonadotropin" in teleosts, participating on the gonadal axis, contributing to gametogenesis and steroidogenesis (Mosconi et al. 2002; Chang and Wong 2009; Pérez et al. 2016). 
The ability to accurately predict time a spawning event would facilitate and allow Piaractus mesopotamicus farmers to organize the next stages of the fry production process, which are the hatchery and nursery stages. Often, nursery ponds are fertilized and prepared to receive the fry, but breeders frequently fail to respond to hormonal inductions. Therefore, in this study, aiming to make the reproduction of this species more secure and predictable, we evaluated the use of salmon gonadotropin-releasing hormone analogue [D-Arg $\left.{ }^{6} \mathrm{Pro}^{9} \mathrm{NEt}\right]-\mathrm{sGnRHa}$ sustained release cholesterol pellets implants $(150 \mu \mathrm{g}$ - Ovaplant@' Western Chemical Inc., USA) in increasing the number of suitable $P$. mesopotamicus females for induced spawning in a predictable period.

\section{Materials and methods}

\section{Maintenance, hormonal induction, and sampling}

Microchipped (AnimallTAG® - Korth RFID Ltda, São Carlos, SP) pacu females were reared in $200 \mathrm{~m}^{3}$ outdoor earthen ponds, stocked at a density of $0.25 \mathrm{fish} / \mathrm{m}^{3}$, at the Aquaculture Center, Sao Paulo State University (Jaboticabal, SP, BR); the females were obtained by induced spawning at the same institution. The earthen ponds received constant flowing water at the rate of $\cong 20 \mathrm{~L} / \mathrm{min}$. The physical and chemical analyses of water were carried out fortnightly before 09:00 h. A YSI model 55 oximeter and a YSI model 63 multiparameter sounder (Yellow Springs Instruments, Yellow Springs, OH, USA) to determine the dissolved oxygen, $\mathrm{pH}$, conductivity levels, and temperature; the concentration of $\mathrm{N}$-ammonia was determined according to the method of Solórzano (1969). The fish were fed a commercially available feed (Guabi, Campinas, SP, BR; composed of 32.0\% crude protein, $6.5 \%$ fat, $10.0 \%$ ash, and $7.0 \%$ crude fiber) twice a day ad libitum. All of the fish were treated and euthanized according to the accepted protocols of the Comissão de Ética no Uso de Animais (CEUA) from the Faculdade de Ciências Agrárias e Veterinárias/Unesp (Jaboticabal, SP, BR) approved on February 09, 2010 (protocol $n^{\circ} 02.116 / 10$ ).

In the middle of spring at " 0 " days after implantation (DAI), to compose the treated group, nine females randomly selected from the earthen ponds were injected with an Ovaplant ${ }^{\circledR}$ implant (Syndel, Qualicum Beach, BC, CA) at a dosage of $150 \mu \mathrm{g}$, using a RALGUN® as the applicator (Syndel, Qualicum Beach, BC, CA). Another nine females were randomly selected as the control group (sham treatment), which received exactly the same procedures as the experimental group, but without the use of implants.

Ovaplant ${ }^{\circledR}$ is a synthetic peptide analogue of salmon gonadotropin-releasing hormone, presented in a cholesterol-based matrix as an intramuscular pellet implant, available in 75,150 , or $250 \mu \mathrm{g}$ sGnRH per pellet. According to tests performed before in fish species, $40-60 \%$ of the sGnRH is released within $24 \mathrm{~h}$, and the remainder is released over the next 7-21 days. Standard hormone dosage rates will be $10-75 \mu \mathrm{g}$ sGnRHa/kg body weight (U.S Fish \& Wildlife Service 2016).

At 0 ( $n=9$ per group), 21 ( $n=4$ per group), 35 ( $n=7$ per group), and $115 \mathrm{DAI}(n=3$ per group), the fish were anesthetized with benzocaine $(0.1 \mathrm{~g} / \mathrm{L})$, the body mass $(\mathrm{BM})$ was weighed $(\mathrm{kg})$, and the fish was photographed. The sample size varied at collection times since we determined that fishing nets would be used no more than two times in the same earthen pond and sampling time; thus, the sample sizes were defined by what was obtained with this effort. This measure was taken to make sure the catch efforts were equal between samplings, 
avoiding different levels of stress that could impact the results. From each digital picture that was taken, the following metric sizes $(\mathrm{cm})$ were determined: standard length (SL) - length of the anterior margin of the head to the posterior margin of the body (insertion of the caudal fin); and abdomen width (AW) - maximum distance of the belly transverse to the body axis. The measurements were taken using the free software IMAGE J (US National Institute of Health, http://rsb.info.nih.gov/ij/); each metric size was taken in triplicate and the means of these rejoinders were used for the analysis, and from this measurement the AW/SL index was also calculated.

Due to the small sample size, which is common in studies with arrays that require low stocking densities and a large number of earthen ponds, we only used two sampling periods, at $35 \mathrm{DAI}(n=5 \mathrm{per}$ group $/ n$ total $=10)$ and $115 \mathrm{DAI}(n=3 \mathrm{per}$ group $/ n$ total $=6)$, when the females were euthanized (benzocaine at $30 \mathrm{~g} / \mathrm{L}$ ) for organ harvesting. The $35 \mathrm{DAI}$ was strategically set because, in other species where similar implants were used, it was observed that gonadotropin levels were maintained at high levels for approximately 4 weeks (Crim et al. 1988), similar to the period of 35 DAI established by us. In the case of $115 \mathrm{DAI}$, this period was determined to be the end of the breeding season, and we needed a second point for comparison between groups. The ovary, liver, viscera, and visceral fat were dissected from each fish and weighed to calculate the following indices: gonadosomatic (GSI), hepatosomatic (HSI), viscerosomatic (VSI), and visceral fat (VFI). All of the indices were calculated according to the following formula: Index $=[(\operatorname{organ}$ weight $(g) / B M(g)) \times 100])$. Additionally, before anesthetic overdose, blood samples $(3 \mathrm{~mL})$ were collected from the caudal vessels at day 0 ( $n=5$ controls), $21 \mathrm{DAI}$ ( $n=4$ per group), $35 \mathrm{DAI}$ ( $n=5$ per group), and 115 DAI ( $n=3$ per group) using EDTA-treated syringes. The serum was separated by centrifuging the samples at $1500 \times \mathrm{g}$ for $15 \mathrm{~min}$ at $4{ }^{\circ} \mathrm{C}$ and stored at $-80^{\circ} \mathrm{C}$ until measurement of the steroid hormone concentrations.

In the last two collections ( 35 and $115 \mathrm{DAI}$ ), the cranial, central, and caudal fragments of the ovarian tissue were fixed with phosphate-buffered $(0.05 \mathrm{M}) 2.5 \%$ glutaraldehyde $(\mathrm{pH} 7.3$ ) for $24 \mathrm{~h}$ at $4{ }^{\circ} \mathrm{C}$ and embedded in Histosec $®$ (Merck KGaA, Darmstadt, HE, GE). The $\cong 1 \mathrm{~g}$ ovarian fragments (medial region) were fixed in modified Gilson solution $(100 \mathrm{~mL} 60 \%$ ethanol, $800 \mathrm{~mL}$ distilled water, $15 \mathrm{~mL} 80 \%$ nitric acid, $18 \mathrm{~mL}$ glacial acetic acid, and $20 \mathrm{~g}$ of mercury chloride) to facilitate the calculation of absolute fecundity rates (AF). Whole pituitaries were preserved in RNAlater ${ }^{\mathrm{TM}}$ solution (Ambion, Austin, TX, USA) according to the manufacturer's instructions and stored at $-80{ }^{\circ} \mathrm{C}$ until total RNA extraction.

\section{Absolute fecundity rates}

The AF was determined by the number of oocytes counted in the fragments that had been submerged in Gilson solution. From the number of oocytes counted the total number of oocytes per a gram of ovary mass was estimated.

\section{Macro and microscopic ovarian maturation stage classification}

The fixed ovarian fragment samples were dehydrated in ethanol, cleared in xylene, and embedded in Histosec ${ }^{\circledR}$ (Merck KGaA, Darmstadt, HE, GE), a paraffin plus plastic resin medium, melted at $58{ }^{\circ} \mathrm{C}$. The samples were sectioned to a thickness of $3.0 \mu \mathrm{m}$ and stained with hematoxylin and eosin. To determine the ovarian maturation stage, a similar analysis to that used by Leonardo et al. (2006), which considers macroscopic (color, shape, size, and 
appearance) and histological aspects, was adopted. To determine the gonadal development stage, we performed a visual analysis and based on the description by Lima et al. (1991), established individually, the frequencies of the oocytes in the following phases: previtellogenic (PV), alveolar cortical (AC), vitellogenic (V), and atresia (AT). Thus, females were classified as one of the following developmental stages: rest, early maturation, advanced maturation, and regression.

\section{Steroid hormones}

The plasma levels of $17 \alpha$-hydroxyprogesterone (17 $\alpha$-OHP), $17 \beta$-estradiol $\left(\mathrm{E}_{2}\right)$, testosterone $(\mathrm{T})$, and 11-ketotestosterone (11-KT) were quantified by hormone enzyme-linked immunosorbent assays (ELISA) using commercial kits (Cayman Chemical Company, Ann Arbor, MI, EUA for 11- KT; and BioCheck, Inc., Foster City, CA, EUA distributed by Interteck Internacional Imp. e Exp. Ltda. Sao Paulo, SP, BR for all others) according to the manufacturer's instructions. The $17 \alpha-\mathrm{OHP}, \mathrm{E}_{2}$, and T plates were read at $450 \mathrm{~nm}$, and the $11-\mathrm{KT}$ plate was read at $405 \mathrm{~nm}$ using a Spectramax 250 ELISA plate reader (Molecular Devices, Inc., Sunnyvale, CA, USA); all of the samples were read in duplicate. The kits were previously validated to pacu by Kuradomi et al. (2016). Females at rest were excluded from the steroid hormones analysis because they could affect the hormones levels since they had not responded to treatment and environmental factors in the control group.

\section{RNA extraction and cDNA synthesis}

Total RNA was extracted from the pituitaries using the RiboPure ${ }^{\mathrm{TM}}$ Kit (Ambion ${ }^{\circledR}$, Austin, TX, USA) following the manufacturer's instructions. The total RNA and the presence of DNA were quantified and confirmed by a Qubit ${ }^{\mathrm{TM}}$ fluorometer (Invitrogen ${ }^{\mathrm{TM}}$ ) using the Quant-iT ${ }^{\mathrm{TM}}$ RNA Assay Kit (Life Technologies ${ }^{\mathrm{TM}}$, Eugene, OR, USA) and Quant-iT ${ }^{\mathrm{TM}}$ dsDNA HighSensitivity (HS) Assay Kit (Life Technologies ${ }^{\mathrm{TM}}$, Eugene, OR, USA), respectively. The calibrations and quantification were carried out according to the manufacturer's instructions; no sample with DNA contamination was observed. The Agilent 2100 Bioanalyzer and the Agilent RNA 6000 Pico Kit (Agilent Technologies, Palo Alto, CA, USA) were used to evaluate the RNA quality, and RIN values higher than 8.5 were accepted. For reverse transcription quantitative PCR (RT-qPCR), SuperScript ${ }^{\mathrm{TM}}$ II Reverse Transcriptase (Invitrogen $^{\mathrm{TM}}$, Carlsbad, CA, USA) was applied using random hexamer primers (Invitrogen ${ }^{\mathrm{TM}}$, Carlsbad, CA, USA) and $2 \mu \mathrm{g}$ of total RNA as a template.

\section{Real-time quantitative PCR}

Quantitative real-time PCR assays were performed in duplicate using 96-well optical plates on an ABI PRISM® 7900HT Sequence Detection System (Applied Biosystems, Foster City, CA, USA) using the default settings. For each $20 \mu \mathrm{L}$ PCR reaction, $5 \mu \mathrm{L}$ of cDNA (diluted two-fold) was mixed with $900 \mathrm{nM}$ sense primer and $900 \mathrm{nM}$ antisense primer in $2 \times$ SYBR ${ }^{\circledR}$ Green PCR Master Mix (Applied Biosystems, Foster City, CA, USA). The primer sequences, except for $g h$, were the same as those used by Kuradomi et al. (2016): 5'-CCTGGTGTTTCAGACCAGCAT-3'/5'-CGTGCTGATAGATGGTGGAGAA-3'; 5'AAGAATGCGGGAGCTGCA-3'/5'-GGTCTCATACGTCCACTCCCTAAA-3'; 5'-TGGC AAAGATGAGACCCAGAA-3'/5'-GGGTACTCCCAAGACTCGATCAG-3' and 5'-TCTG 
GATGGCACGGAGACA-3'/5'-CAATCTTCCATCCCTTGAACCA-3' - the sense/antisense to the genes expressions of $l h b, f s h b, g h$, and elongation factor 1 alpha (efla), respectively. Target $(g h, f s h$, and $l h b)$ gene expression was normalized to efla gene expression and calibrated by using the mean of the pituitary efla expression levels from the control sampling period. PCR efficiency was evaluated according to the equation $C t=m \times(\log \mathrm{Q})+c$, where $C t$ is the threshold cycle, $Q$ is the initial copy number, $c$ is the intercept on the $y$ axis, and $m$ is the slope (Bogerd et al. 2001). A fourfold serial dilution of the pituitary cDNA mixture was performed, and all of the primer sets showed a standard curve with a slope value that was close to 2 , indicating exponential PCR amplification, assuming that 2 cycles are required to generate a fourfold increase in the PCR product. To calculate gene expression levels, the $\Delta \Delta \mathrm{Ct}$ method was used, as previously described (Bogerd et al. 2001) and applied by Kuradomi et al. (2016). The females classified as rest were also excluded from the analyses of gene expression.

\section{Statistical analysis}

The statistical analyses were performed using specialized statistical software (STATISTICAStatSoft, Inc., Tulsa, OK, USA) and Excel (Microsoft, Redmond, USA). Assumptions of normality and homoscedasticity were tested by Shapiro-Wilk's and Levene's tests, respectively. Parametric variables (biometrics data, AW/SL, tangible indices, and fecundity) were assessed using Student's $t$ test. For the hormone levels and gene expression data, the nonparametric Mann-Whitney U tests were used. Significance $(\alpha=0.05)$ was determined for all of the datasets, and the results are shown as the mean \pm standard error of the mean (SEM).

\section{Results}

\section{Water parameters}

Maximum and minimum variations and mean \pm SEM of the temperature $\left(22\right.$ to $30{ }^{\circ} \mathrm{C}$; $25.91 \pm 2.98), \mathrm{pH}(6.59$ to $7.46 ; 6.94 \pm 0.13)$, conductivity (41 to $122 \mu \mathrm{S} / \mathrm{cm}$; $52.10 \pm 10.27)$ total ammonia ( 0.00 to $0.50 \mathrm{ppm} ; 0.25 \pm 0.05)$, and dissolved oxygen (4.26 to $7.46 \mathrm{mg} / \mathrm{L} ; 5.89 \pm 0.51)$ of the earthen ponds water was satisfactory throughout the experimental period, remaining within the recommended levels for South American teleost broodstock (Bock and Padovani 2000; Murgas et al. 2009).

\section{Gene expression by quantitative real-time PCR}

The mean values of the relative gene expression of $f$ sh $b$ at $35 \mathrm{DAI}$ in the treated females was $\times 1.45$ lower than the controls $(P<0.05)$, but similar to all other mean values $(P>0.05)$ (Fig. 1). Additionally, in the same sampling, the mean value of $l \mathrm{hb}$ expression of the treated females was $\times 1.64$ higher than all other mean values $(P<0.05)$. The mean values of $g h$ gene expression were similar in all the periods $(P>0.05)$ (Fig. 1).

\section{Steroid hormones}

The mean values of the $\mathrm{E}_{2}, \mathrm{~T}, 17 \alpha$-OHP, and 11-KT plasma levels were similar $(P>0.05)$ between the groups at same sampling (Fig. 2). However, we observed a trend of gradual 


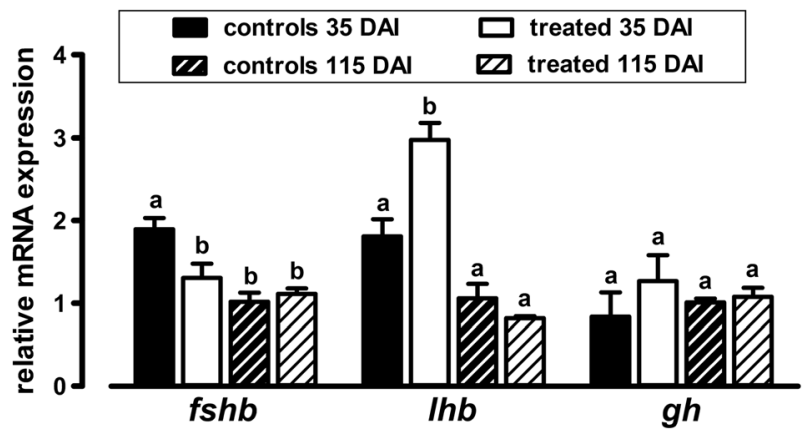

Fig. 1 Relative expression of $f s h b, l h b$, and $g h$ mRNA in the pituitary, comparing treated (sGnRHa - $150 \mu \mathrm{g}$ ) and control pacu (Piaractus mesopotamicus) females. Different letters represent significant differences between the groups $(P<0.05)$

reduction in the $\mathrm{E}_{2}$ and 11-KT levels in both groups between 21 (onset of spawning season) and 115 DAI (ovarian regression phase) (Fig. 2). Regarding 17 $\alpha$-OHP and T, we observed similar levels between groups during the entire experimental period (Fig. 2).

\section{Morphometry, index, and AF}

The means of biometric data are presented in Table 1, which shows that the values were similar $(P>0.05)$ for all variables in both groups (AW, SL, BM, and AW/SL).

The mean values of tangible indices, shown in Table 2, were similar between the groups $(P>0.05)$, except for the HSI which was higher in the treated group at 35 and 115 DAI $(P<0.05)$. The mean values observed for AF data were also similar between groups at 35 and 115 DAI (Table 2).

\section{Ovarian maturation stage}

The ovarian maturation, defined both macroscopically and microscopically, is shown in Fig. 3. The percentages of ovaries in different maturation classes in each group are presented in Fig. 4.

\section{Discussion}

The use of sGnRHa implants (150 $\mathrm{g}$ Ovaplant $\left.{ }^{\circledR}\right)$ was associated with a higher frequency of females suitable for hormonal induction at 35 DAI, when 60\% (3 of 5) and were in the advanced maturation stage in the treated and $20 \%$ (1 of 5) control groups. The higher percentage of females in an advanced stage of maturity at 35 DAI in the treated group was accompanied by higher values of $l h b$ expression, higher HSI values, and lower values of $f s h b$ expression in comparison to the control group. Taken together, these findings indicated that the implants have potential to promote changes on the ovarian maturation process between 0 and 35 DAI in treated females.

In this context, it is known that the GnRH controls the secretion and release of Lh (Trudeau et al. 1991; Trudeau 1997; Golan et al. 2015), which is responsible for promoting the final maturation processes and ovulation in fish (Lubzens et al. 2010, Ogiwara et al. 2013). Therefore, an intensified $l \mathrm{hb}$ gene expression at $35 \mathrm{DAI}$ in treated animals (64\% more) was 


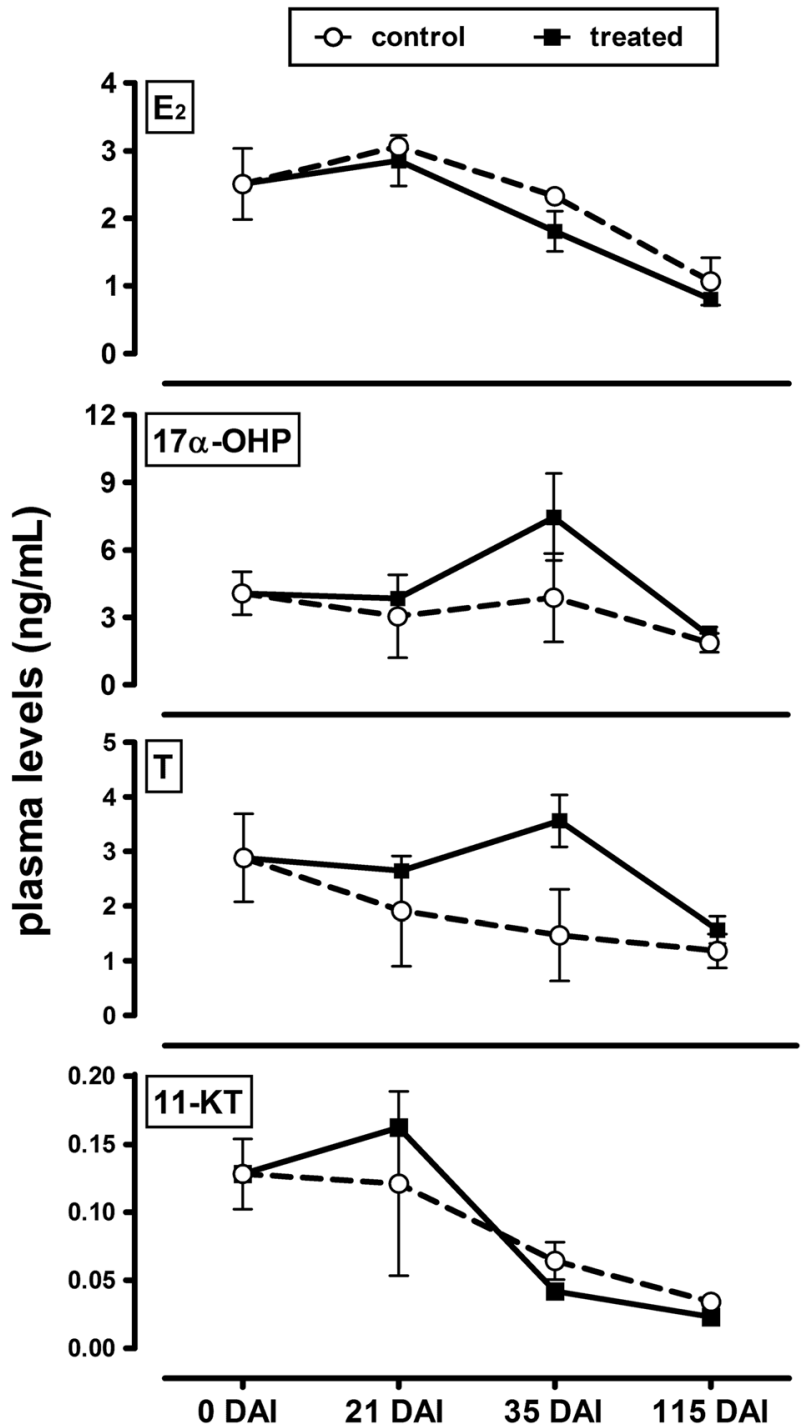

Fig. 2 Plasma $17 \alpha$-hydroxyprogesterone (17 $\alpha$-OHP), $17 \beta$-estradiol $\left(\mathrm{E}_{2}\right)$, testosterone $(\mathrm{T})$, and 11ketotestosterone $(11-\mathrm{KT})$ levels $($ mean $\pm \mathrm{SE})$ in treated $(\mathrm{sGnRHa}-150 \mu \mathrm{g})$ and control pacu females (Piaractus mesopotamicus) throughout the breeding season. DAI days after introduction of the implant. Day " 0 " beginning of the experiment

associated with a higher frequency of females in the advanced stage of maturation (suitable for hormonal induction). Similar results were observed in sea bass (Dicentrarchus labrax) sGnRHa implant treated females, where the synthesis and release of Lh was stimulated (Mateos et al. 2002); and in sockeye salmon (Oncorhynchus nerka), in which the use of GnRHa implants induced the Lh transcription level and anticipated the final maturation of mature females (Kitahashi et al. 1998).

Despite being associated with a higher frequency of advanced maturation class females and pronounced changes in $l \mathrm{hb}$ expression, the use of ( $\mathrm{sGnRHa}-150 \mu \mathrm{g})$ implants applied here 


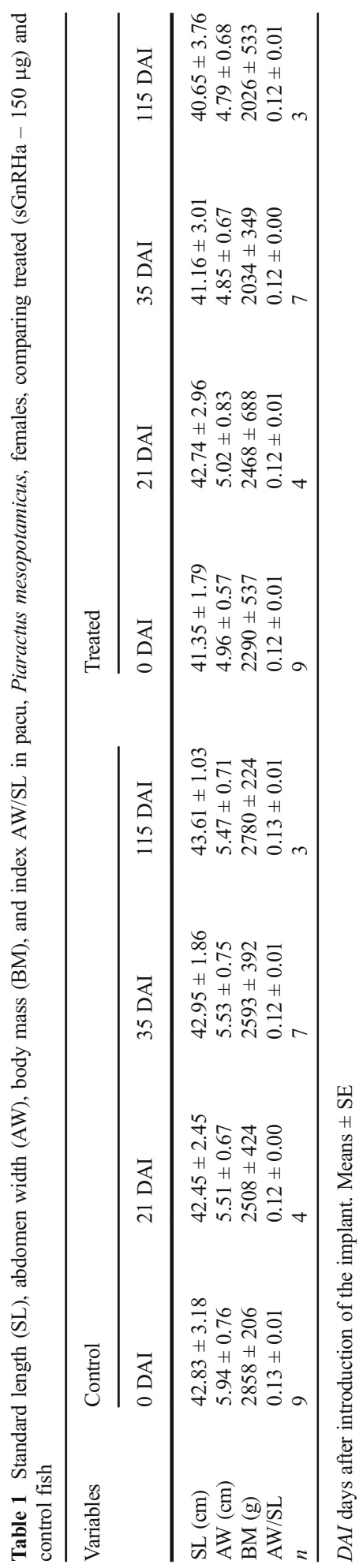


Table 2 The tangible indices and absolute fecundity - AF ( $\mathrm{n}^{\circ}$ of oocytes/g of ovary) (means $\pm \mathrm{SE}$ ) of treated $(\mathrm{sGnRHa}-150 \mu \mathrm{g})$ and control fish in pacu, Piaractus mesopotamicus, females

\begin{tabular}{|c|c|c|c|c|}
\hline \multirow[t]{2}{*}{ Variables } & \multicolumn{2}{|l|}{ Control } & \multicolumn{2}{|l|}{ Treated } \\
\hline & 35 DAI & 115 DAI & 35 DAI & 115 DAI \\
\hline HSI & $0.78 \pm 0.03 *$ & $0.68 \pm 0.08 *$ & $0.94 \pm 0.03$ & $0.96 \pm 0.08$ \\
\hline GSI & $3.63 \pm 0.60$ & $4.82 \pm 1.28$ & $4.47 \pm 1.19$ & $4.49 \pm 0.21$ \\
\hline VSI & $6.01 \pm 0.48$ & $6.53 \pm 2.58$ & $6.77 \pm 0.38$ & $4.37 \pm 2.37$ \\
\hline VFI & $2.59 \pm 0.38$ & $2.13 \pm 1.13$ & $3.02 \pm 0.38$ & $1.35 \pm 0.55$ \\
\hline $\mathrm{AF}$ & $920.00 \pm 80.00$ & $970.00 \pm 71.00$ & $880.00 \pm 174.00$ & $888.00 \pm 260.00$ \\
\hline$n$ & 5 & 3 & 5 & 3 \\
\hline
\end{tabular}

Asterisks denote significant differences between groups on the same date $(P<0.05)$

Hepatosomatic HSI, gonadosomatic GSI, viscerosomatic VSI, visceral fat index VFI, and DAI days after introduction of the implant

was not able to cause all treated females to reach the advanced maturation class in the same period (35 DAI). However, we also observed that at the concentration applied here, the use of implants did not significantly alter the GSI, the fecundity absolute or the concentrations of gonadal steroids. These results allow us to make some assessments on the dose applied and the results obtained. Considering that it is a pioneering study on tropical total spawning fish and that we showed that the species is probably responsive to the technique and the next steps would be to search for more effective doses followed by pharmacological studies.
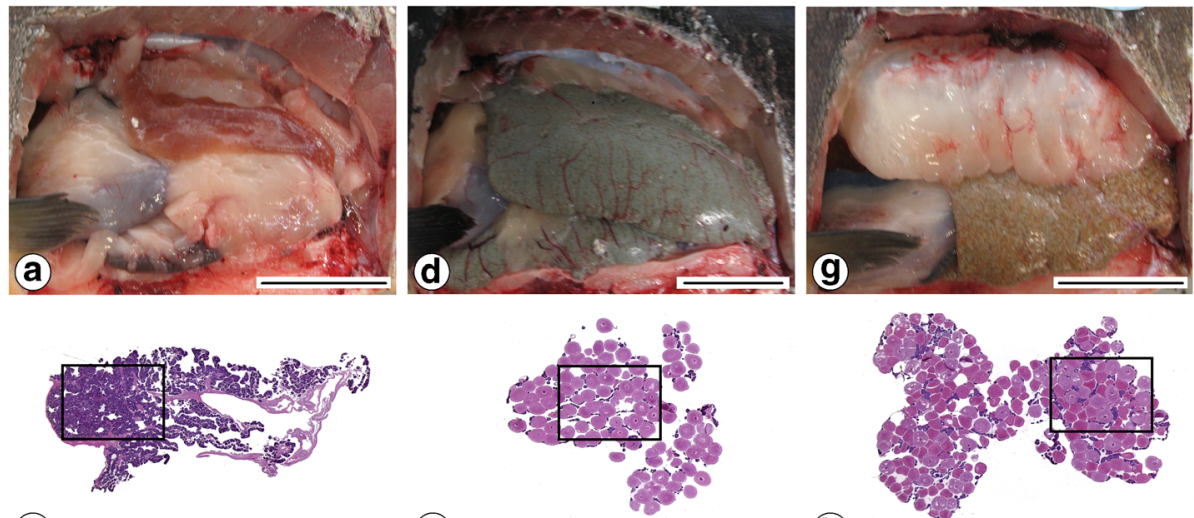

(b)

(e)

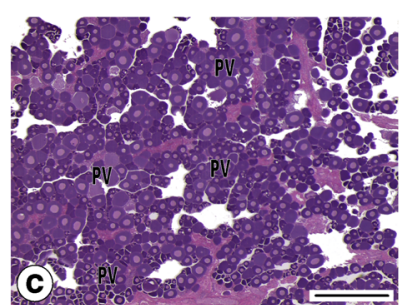

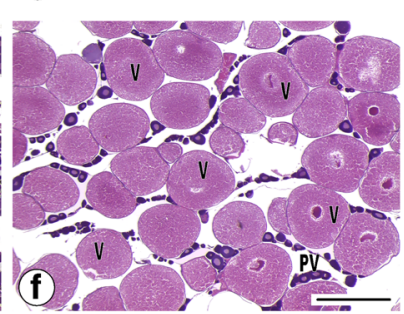

(h)
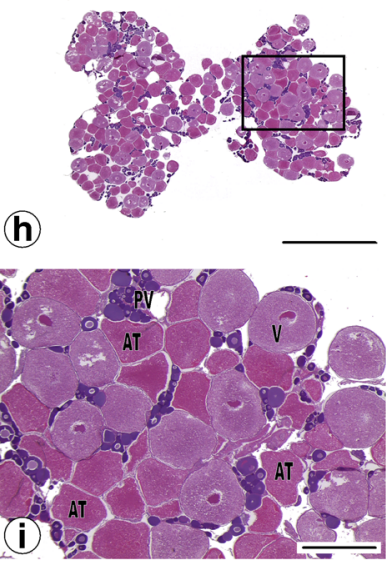

Fig. 3 Illustrative figures of the ovaries (A, D, and G) and photomicrographs of histological sections (B, C, E, F, G, and I) of pacu, Piaractus mesopotamicus, in the following stages: rest (A-C), advanced maturation (D-F), and regression $(\mathrm{G}-\mathrm{I})$. In the figures, B, E, and $\mathrm{H}$ the frame ( $\square$ ) represents the area enlarged in Figs. C, F, I. Previtellogenic $(\mathrm{PV})$ vitellogenic $(\mathrm{V})$, and atretic oocytes $(\mathrm{AT})$. Scale bars $=5 \mathrm{~cm}(\mathrm{~A}, \mathrm{D}$ and $\mathrm{G}), 5 \mathrm{~mm}(\mathrm{~B}, \mathrm{E}, \mathrm{H})$, and $1 \mathrm{~mm}(\mathrm{C}, \mathrm{F}, \mathrm{I})$ 


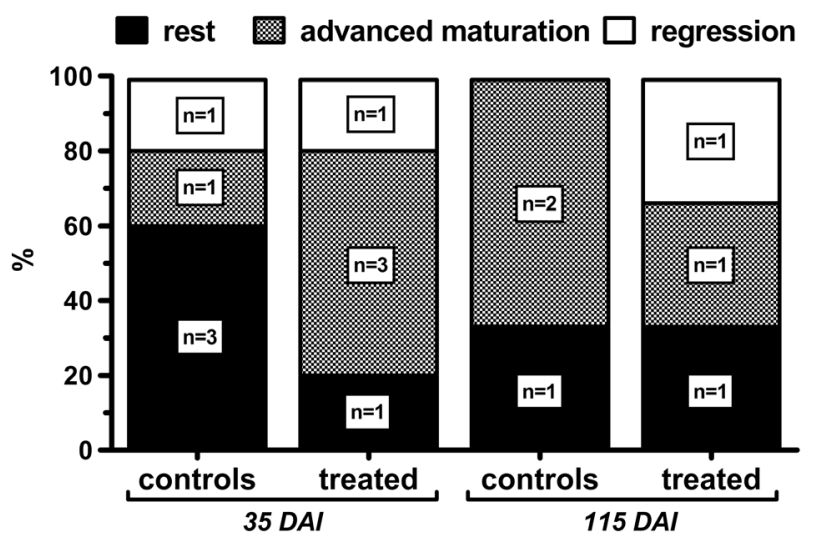

Fig. 4 Frequency of pacu ovaries (Piaractus mesopotamicus) classified by histology in the stages of rest, advanced maturation, and regression. DAI days after introduction of the implant

In this regard, optimum doses for induced successful spawning using a GnRHa implant have been reported for Sparus aurata (Barbaro et al. 1997) and Lates calcarifer (Garcia 1989), which spawned successfully using doses from $37.5-80 \mu \mathrm{g}$ GnRHa $/ \mathrm{kg}$ of fish BM. In the case of Lutjanus guttatus, higher doses ranging from 240 to $280 \mu \mathrm{g} \mathrm{GnRHa} / \mathrm{kg}$ of fish BM (IbarraCastro and Duncan 2007) were required, as such, the optimum doses seems to be species specific. Moreover, Carolsfeld et al. (1988b) found that the maturation response in Clupea harengus pallasi was dose-dependent and the higher tested dose (approximately 800-1000 $\mu \mathrm{g}$ $\mathrm{GnRHa} / \mathrm{kg}$ of fish BM) was more effective than the lower dose (approximately 170-220 $\mu \mathrm{g}$ $\mathrm{GnRHa} / \mathrm{kg}$ of fish BM). Therefore, based on the differences among doses previously reported for spawning induction and sexual maturation, it is reasonable to suggest that higher doses than the one applied here for P. mesopotamicus could provide better results for inducing sexual matura-

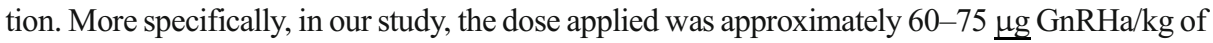
fish BM, so higher doses could be tested to verify whether a higher proportion of advanced maturation class pacu females at a predictable time would occur, as reported for Clupea harengus pallasi by Carolsfeld et al. (1988b).

Concerning gonadal steroid levels, in species treated with GnRHa implants, changes in Lh or lhb levels may (Harmin et al. 1995; Kumakura et al. 2003) or may not (Mañanós et al. 2002) be accompanied by changes in levels of the related gonadal steroids, even during the same period, with expressive variations between species and studies. Still in this concern, we must emphasize that, due to the absence of specific kits, we evaluated the values of the precursor $17 \alpha$-OHP, but not $17 \alpha, 20 \beta$-dihydroxy-4-pregnen-3-one (DHP). Nevertheless, it is known that, in captivity, DHP peaks are found in the females of most farmed fish close to the ovulation (Nagahama and Yamashita 2008; Mylonas et al. 2010), usually in females that are hormonally induced for spawning. Additionally, eventual peaks of $17 \alpha$-OHP may have occurred outside of the analysis period (35 and $110 \mathrm{DAI}$ ), especially since gonadotropins and steroids may not necessarily have the same patterns of synthesis and release (Mylonas and Zohar 2007).

Similar results were observed concerning $\mathrm{E}_{2}$; despite the $f_{s} h b$ levels being higher in the control then in the treated group at $35 \mathrm{DAI}$, the $\mathrm{E}_{2}$ plasma levels were similar between groups. In this concern, one would expect higher levels of $\mathrm{E}_{2}$ in the control group due to the higher $f_{s} h b$ levels, but no parallel was found, similar to the $l h b$ and $17 \alpha-\mathrm{OHP}$ relationship. It is known that, in fish, there is an intensification of vitellogenic processes concurrent to an elevation in $E_{2}$ plasma levels (Berlinsky and Specker 1991; Lubzens et al. 2010; Yilmaz et al. 2015). However, 
in this study, similar levels of $\mathrm{E}_{2}$ were in agreement with the results found; at $35 \mathrm{DAI}$, maturing females (in vitellogenesis) were not found in both groups, and a similar average GSI was found between groups at 35 DAI. Profiles of plasma concentrations of $E_{2}$ in the treated and control females of this study were similar to those described for other total spawner fish analyzed during breeding seasons (Arantes et al. 2010; Lubzens et al. 2010; Hainfellner et al. 2012; Yilmaz et al. 2015). However, a clearer understanding of the relationships between the use of implants in P. mesopotamicus and the levels of $\mathrm{E}_{2}$, as well as of $17 \alpha-\mathrm{OHP}$ or DHP still depends on further studies using a higher number of implant doses (treatments) with more replicates.

The higher HSI values of treated females at 35 DAI were in accordance with the increased number of advanced maturation females in the treated group since the vitellogenin proteins are synthesized in the liver (Nagahama and Yamashita 2008; Lubzens et al. 2010; Yilmaz et al. 2015). Moreover, and also for this reason, higher HSI values during vitellogenesis than at spawning and/or resting have been reported in several fish species (Santos et al. 2004; Sudarshan and Kulkarni 2013; Hismayasari et al. 2015; Jan and Ahmed 2016).

In this study, we did not observe a relationship between the use of sGnRHa and $g h$ expression. Similarly, in African catfish (Clarias gariepinus), no association between $\mathrm{GnRH}$ and Gh concentrations was found (Lescroart et al. 1996; Bosma et al. 1997). Here, we investigated $g h$ expression profiles to have a broad range evaluation of the effects of sGnRH implants since, in other fish species, GnRH has been shown to provoke Gh synthesis and release, which in turn, acts as "co-gonadotropin" over gonadal gametogenesis and steroidogenesis (Chang and Wong 2009; Xu et al. 2011; Sun et al. 2014). Additionally, elevated serum $\mathrm{Gh}$ is associated with an inhibition of pituitary $l \mathrm{hb}$ expression and Lh secretion (Cao et al. 2014). However, we must consider that the action of $\mathrm{GnRH}$ on $g h$ gene expression, and consequent elevation in Gh plasma concentration, is dependent on the gonad maturation stage (Sumpter et al. 1991; Björnsson et al. 1994; Gomez et al. 1999) or season (Bhandari et al. 2003). Therefore, while we could not demonstrate a clear association between the results found and $g h$ gene expression levels in this study, the specific role of this substance in ovarian maturation and its association with the use of implants in this species is a subject for further studies.

The use of slow-release hormone implants has been widely used in freshwater (Mylonas et al. 1992, 1995) and marine fish species (Mylonas et al. 1998; Forniés et al. 2001; Mañanós et al. 2002; Marino et al. 2003; Aramli et al. 2016). Most of the results were obtained with multiple spawner fish that spawn naturally in artificial environment conditions. In these species, the use of implants can increase the number of spawning fish and their associated fertility rates (Mylonas et al. 1998, 2003). In this regard, we found from the present study that GnRH implants can be used for a slightly different purpose in total spawner egg laying fish; that is, promoting a higher number of females suitable for induced spawning at a predictable time.

In summary, we observed that at $35 \mathrm{DAI}$, the use of $150 \mu \mathrm{g}$ sGnRHa implants increased $l h b$ expression, HSI levels, and the frequency of females in advanced maturation in this study. Although many issues for further testing were raised by this study, the results obtained here indicate that the sGnRHa slow-release implants shows promise for accelerating maturation in P. mesopotamicus.

Acknowledgements This work was supported by FAPESP (grant 2010/05286-1), São Paulo Research Foundation (FAPESP). R.Y.K. was supported by FAPESP (grant 2010/00825-1) and Coordenação de Aperfeiçoamento de Pessoal de Nivel Superior (CAPES - Process BEX 8501/11-4). 


\section{References}

Acuña JJA, Rangel JLH (2009) Effects of hypophysial extract of common carp and the analog of the GnRH on the final maturation oocyte and the spawning of cachama negra (Colossoma macropomum). Rev Cient FCVLUZ 19:486-494

Aizen J, Meiri I, Tzchori I, Levavi-Sivan B, Rosenfeld H (2005) Enhancing spawning in the grey mullet (Mugil cephalus) by removal of dopaminergic inhibition. Gen Comp Endocrinol 142:212-221

Aramli MS, Nazari RM, Farsi P, Mehdinejad N, Aramli S, Sotoudeh E (2016) Effectiveness of carp pituitary extract and luteinizing hormone releasing hormone analogue administration (by either injection or cholesterol pellet implantation) on spawning performance in female sturgeon, Huso huso Aquac Res 1-8

Arantes FP, Santos HB, Rizzo E, Sato Y, Bazzoli N (2010) Profiles of sex steroids, fecundity, and spawning of the curimatã-pacu Prochilodus argenteus in the São Francisco River, downstream from the Três Marias Dam, Southeastern Brazil. Anim Reprod Sci 118:330-336

Barbaro A, Francescon A, Bozzato G, Belvedere P, Colombo L (1997) Induction of spawning in the gilthead seabream, Sparus aurata L., by a long-acting GnRH agonist and the effect on egg quality and daily timing of spawning. Aquaculture 154:349-359

Berlinsky DL, Specker JL (1991) Changes in gonadal hormones during oocyte development in the striped bass, Morone saxatilis. Fish Physiol Biochem 9:51-62

Bhandari RK, Taniyama S, Kitahashi T, Ando H, Yamauchi K, Zohar Y, Ueda H, Urano A (2003) Seasonal changes of responses to gonadotropin-releasing hormone analog in expression of growth hormone/prolactin/ somatolactin genes in the pituitary of masu salmon. Gen Comp Endocrinol 130:55-63

Björnsson BT, Taranger GL, Hansen T, Stefansson SO, Haux C (1994) The interrelation between photoperiod, growth hormone, and sexual maturation of adult Atlantic salmon (Salmo salar). Gen Comp Endocrinol 93:70-81

Bobe J, Labbé C (2010) Egg and sperm quality in fish. Gen Comp Endocrinol 165:535-548

Bock CL, Padovani CR (2000) Considerações sobre a reprodução artificial e alevinagem de pacu (Piaractus mesopotamicus, Holmberg, 1887) em viveiros. Acta sci Biol sci 22:495-501

Bogerd J, Blomenrohr M, Andersson E, van der Putten HH, Tensen CP, Vischer HF, Granneman JC, JanssenDommerholt C, Goos HJ, Schulz RW (2001) Discrepancy between molecular structure and ligand selectivity of a testicular follicle-stimulating hormone receptor of the African catfish (Clarias gariepinus). Biol Reprod 64:1633-1643

Bosma PT, Kolk SM, Rebers FEM, Lescroart O, Roelants I, Willems PHG, Schulz RW (1997) Gonadotrophs but not somatotrophs carry gonadotrophin-releasing hormone receptors: receptor localization, intracellular calcium, and gonadotrophin and GH release. J Endocrinol 152:437-446

Brooks S, Tyler CR, Sumpter JP (1997) Egg quality in fish: what makes a good egg? Rev Fish Biol Fisher 7:387-416

Campbell PM, Pottinger TG, Sumpter JP (1992) Stress reduces the quality of gametes produced by rainbow trout. Biol Reprod 47:1140-1150

Campbell PM, Pottinger TG, Sumpter JP (1994) Preliminary evidence that chronic confinement stress reduces the quality of gametes produced by brown and rainbow trout. Aquaculture 120:151-169

Carneiro PCF, Mikos JD (2008) Gonadotrofina coriônica humana e hormônio liberador de gonadotrofina como indutores da reprodução do jundiá. Acta Sci Anim Sci 30:345-350

Cao M, Chen J, Peng W, Wang Y, Liao L, Li L, Trudeau VL, Zhu Z, Hu W (2014) Effects of growth hormone over-expression on reproduction in the common carp Cyprinus carpio L. Gen Comp Endocrinol 195:47-57

Carolsfeld J, Ramos SM, Ormanezi R, Gomes JH, Barbosa JM, Harvey B (1988a) Analysis of protocols for application of an LHRH analog for induced final maturation and ovulation of female pacu (Piaractus mesopotamicus Holmberg 1887). Aquaculture 74:49-55

Carolsfeld J, Sherwood NM, Kreiberg H, Sower SA (1988b) Induced sexual maturation of herring using GnRH "quick-release" cholesterol pellets. Aquaculture 70:169-181

Chang JP, Wong AOL (2009) Growth hormone regulation in fish: a multifactorial model with hypothalamic, peripheral and local Autocrine/paracrine signals. In: Van Der Kraak G, Farrell AP, Brauner CJ (eds) Bernier NJ. Academic Press, Vermont, Fish Physiology, pp 151-195

Crim LW, Sherwood NM, Wilson CE (1988) Sustained hormone release. II. Effectiveness of LHRH analog (LHRHa) administration by either single time injection or cholesterol pellet implantation on plasma gonadotropin levels in a bioassay model fish, the juvenile rainbow trout. Aquaculture 74:87-95

Criscuolo-Urbinati E, Kuradomi RY, Urbinati EC, Batlouni SR (2012) The administration of exogenous prostaglandin may improve ovulation in pacu (Piaractus mesopotamicus). Theriogenology 78:2087-2094

Forniés MA, Mañanos E, Carrillo M, Rocha A, Laureau S, Mylonas CC, Zohar Y, Zanuy S (2001) Spawning induction of individualised European seabass females (Dicentrarchus labrax) using different GnRHadelivery systems. Aquaculture 202:221-234 
Garcia LMB (1989) Dose-dependent spawning response of mature female sea bass, Lates calcarifer (Bloch), to pelleted luteinizing hormone-releasing hormone analogue (LHRHa). Aquaculture 77:85-96

Gelman A, Drabkin V, Sachs O, Chechic K, Gabay I, Glatman L (2004) Pacu (Piaractus mesopotamicus) a new fish species in israeli aquaculture: possibility of utilization. More Efficient Utilization of Fish and Fisheries Products: $75-83$

Golan M, Zelinger E, Zohar Y, Levavi-Sivan B (2015) Architecture of GnRH-gonadotrope-vasculature reveals a dual mode of gonadotropin regulation in fsh. Endocrinology 156:4163-4173

Gomez JM, Weil C, Ollitrault M, Le Bail PY, Breton B, Le Gac F (1999) Growth hormone (GH) and gonadotropin subunit gene expression and pituitary and plasma changes during spermatogenesis and oogenesis in rainbow trout (Oncorhynchus mykiss). Gen Comp Endocrinol 113:413-428

Hainfellner P, De Souza TG, Moreira RG, Nakaghi LSO, Batlouni SR (2012) Gonadal steroids levels and vitellogenesis in the formation of oocytes in Prochilodus lineatus (Valenciennes) (Teleostei: Characiformes). Neotrop ichthyol 10:601-612

Harmin SA, Crim LW, Wiegand MD (1995) Manipulation of the seasonal reproductive cycle in winter flounder, Pleuronectes americanus, using a gonadotropic hormone-releasing hormone. Mar Biol 121:611-619

Hismayasari IB, Marhendra APW, Rahayu S, Saidin SDS (2015) Gonadosomatic index (GSI), hepatosomatic index (HSI) and proportion of oocytes stadia as an indicator of rainbowfish Melanotaenia boesemani spawning season. Int J Fish Aquat Stud 2:359-362

Ibarra-Castro L, Dunca NJ (2007) GnRHa-induced spawning of wild-caught spotted rose snapper Lutjanus guttatus. Aquaculture 272:737-746

Instituto Brasileiro de Geografia e Estatística - IBGE (2015). Produção da Pecuária Municipal.http://biblioteca. ibge.gov.br/visualizacao/periodicos/84/ppm_2014_v42_br.pdf. Accessed 23 September 2016

Jan M, Ahmed I (2016) Assessment of fecundity, gonadosomatic index and hepatosomatic index of snow trout, Schizothorax plagiostomus in river Lidder, from Kashmir Himalaya, India. Int J Fish Aquat Stud 4:370-375

Kitahashi T, Alok D, Ando H, Kaeriyama M, Zohar Y, Ueda H, Urano A (1998) GnRH analog stimulates gonadotropin II gene expression in maturing sockeye salmon. Zool Scien 15:761-765

Kumakura N, Okuzawa K, Gen K, Kagawa H (2003) Effects of gonadotropin-releasing hormone agonist and dopamine antagonist on hypothalamus-pituitary-gonadal axis of pre-pubertal female red seabream (Pagrus major). Gen Comp Endocrinol 131:264-273

Kuradomi RY, Sousa GT, Foresti F, Schulz RW, Bogerd J, Moreira RG, Furlan LR, Almeida EA, Maschio LR, Batlouni SR (2016) Effects of re-stripping on the seminal characteristics of pacu (Piaractus mesopotamicus) during the breeding season. Gen Comp Endocr 225:162-173

Lee CS, Tamaru CS, Banno JE, Kelley CD (1986) Influence of chronic administration of LHRH-analogue and/or 17a-methyltestosterone on maturation in milkfish, Chanos chanos. Aquaculture 59:147-159

Leonardo AFG, Romagosa E, Batlouni SR, Borella MI (2006) Occurrence and significance of ovarian and follicular regression in cachara Pseudoplatystoma fasciatum (Linnaeus, 1766): a histology approach. Arq Bras Med Vet Zoo 58:831-840

Lescroart O, Roelants I, Mikolajczyk T, Schulz RW, Bosma PT, Khun ER, Ollevier F (1996) A radioimmunoassay for African catfish growth hormone: validation and effect of substances modulating the release of growth hormone. Gen Comp Endocrinol 104:147-155

Lima RVA, Bernardino G, Val-Sella MV, Fava-de-Moraes F, Schemy RA, Borella MI (1991) Tecido germinativo ovariano e ciclo reprodutivo de pacus (Piaractus mesopotamicus, Holmberg, 1887) mantidos e cativeiro. Bol Téc CEPTA 4:1-46

Lubzens E, Young G, Bobe J, Cerda J (2010) Oogenesis in teleosts: how eggs are formed. Gen Comp Endocrinol 165:367-389

Mañanós E, Carrillo M, Sorbera LA, Mylonas CC, Asturiano JF, Bayarri MJ, Zohar Y, Zanuy S (2002) Luteinizing hormone (LH) and sexual steroid plasma levels after treatment of European sea bass with sustained-release delivery systems for gonadotropin-releasing hormone analogue (GnRHa). J Fish Biol 60:328-339

Marino G, Panini E, Longobardi A, Mandich A, Finoia MG, Zohar Y, Mylonas CC (2003) Induction of ovulation in captive-reared dusky grouper, Epinephelus marginatus (Lowe, 1834) with a sustained-release GnRHa implant. Aquaculture 219:841-858

Mateos J, Mananos E, Carrillo M, Zanuy S (2002) Regulation of follicle stimulating hormone (FSH) and luteinizing hormone $(\mathrm{LH})$ gene expression by gonadotropin-releasing hormone $(\mathrm{GnRH})$ and sexual steroids in the Mediterranean sea bass. Comp Biochem Physiol B 132:75-86

Moro GV, Rezende FP, Alves AL, Hashimoto DT, Varela ES, Torati LS (2013) Espécies de peixe para piscicultura. In: Rodrigues APO, Lima AF, Alves AL, Rosa DK, Torati LS, Santos VVR (eds) Piscicultura de água doce: Multiplicando conhecimentos, 1st edn. Embrapa, Brasília, pp 29-68

Mosconi G, Carnevali O, Habibi HR, Sanyal R, Polzonetti-Magni AM (2002) Hormonal mechanisms regulating hepatic vitellogenin synthesis in the gilthead sea bream, Sparus aurata. Am J Phys 283: C673-C678 
Murgas LDS, Drummond MM, Pereira GJM, Felizardo VO (2009) Manipulação do ciclo e da eficiência reprodutiva em espécies nativas de peixes de água doce. Rev Bras Reprod Anim 6:70-76

Mylonas CC, Hinshaw JM, Sullivan CV (1992) GnRHa-induced ovulation of brown trout (Salmo trutta) and its effects on egg quality. Aquaculture 106:379-392

Mylonas CC, Tabata Y, Langer R, Zohar Y (1995) Preparation and evaluation of polyanhydride microspheres containing gonadotropin-releasing hormone $(\mathrm{GnRH})$, for inducing ovulation and spermiation in fish. J Control Release 35:23-34

Mylonas CC, Woods LC, Thomas P, Zohar Y (1998) Endocrine profiles of female striped bass (Morone saxatilis) in captivity, during post-vitellogenesis and induction of final oocyte maturation via controlled-release GnRHa-delivery systems. Gen Comp Endocrinol 110:276-289

Mylonas CC, Sigelaki I, Divanach P, Mañanós E, Zanuy S, Afonso-Polyviou A (2003) Multiple spawning of individual European sea bass ( Dicentrarchus labrax) after repeated injections of GnRHa, and evaluation of egg quality. Aquaculture 221:605-620

Mylonas CC, Zohar Y (2007) Promoting oocyte maturation, ovulation and spawning in farmed fish. In: Babin PJ, Cerdá J, Lubzens E (eds) The fish oocyte: from basic studies to biotechnological applications. Kluwer Academic Publishers, Dordrecht, pp 433-470

Mylonas CC, Fostier A, Zanuy S (2010) Broodstock management and hormonal manipulations of fish reproduction. Gen Comp Endocrinol 165:516-534

Nagahama Y, Yamashita M (2008) Regulation of oocyte maturation in fish. Develop Growth Differ 50:S195-S219

Ogiwara K, Fujimori C, Rajapakse S, Takahashi T (2013) Characterization of luteinizing hormone and luteinizing hormone receptor and their indispensable role in the ovulatory process of the medaka. PLoS One 8:E54482

Paulino MS, Sampaio M, Miliorini AB, Murgas LDS, Lima FSM, Felizardo VO (2011) Desempenho reprodutivo do pacu, piracanjuba e curimba induzidos com extrato de buserelina. Bol Inst Pesca 37:39-45

Pereira TSB, Boscolo CNP, Moreira RG, Batlouni SR (2017) The use of mGnRHa provokes ovulation but not viable embryos in Leporinus macrocephalus. Aquacult Int 25:515-529

Pérez L, Ortiz-Delgado JB, Manchado M (2016) Molecular characterization and transcriptional regulation by GH and GnRH of insulin-like growth factors I and II in white seabream (Diplodus sargus). Gene 578:251-262

Romagosa E, Godinho HM, Braga FM (1993) Mudanças morfológicas dos ovários de pacu, Piaractus mesopotamicus (Holmberg, 1887), em condições de confinamento. Bol Inst Pesca 20:67-80

Santos JE, Bazzoli N, Rizzo E, Santos GB (2004) Reproduction of the catfish Iheringichthys labrosus (Lütken) (Pisces, Siluriformes) in Furnas reservoir, Minas Gerais, Brazil. Rev Bras Zool 21:193-200

Schreck CB (2010) Stress and fish reproduction: the roles of allostasis and hormesis. Gen Comp Endocrinol 165:549-556

Solórzano L (1969) Determination of ammonia in natural waters by the phenolhypochlorite method. Limnol Oceanogr 14:799-801

Sudarshan S, Kulkarni RS (2013) Determination of condition factor (K) somatic condition factor (Ks) hepatic and gonadosomatic indices in the fresh water fish Notopterus Notopterus. International Journal of Scientific Research 2:524-526

Sumpter JP, Lincoln RF, Bye VJ, Carragher JF, Le Bail PY (1991) Plasma growth hormone levels during sexual maturation in diploid and triploid rainbow trout (Oncorhynchus mykiss). Gen Comp Endocrinol 83:103-110

Sun C, He M, Ko WK, Wong AO (2014) Mechanisms for luteinizing hormone induction of growth hormone gene transcription in fish model: crosstalk of the cAMP/PKA pathway with MAPK-and PI3K-dependent cascades. Mol Cell Endocrinol 382:835-850

Trudeau VL, Peter RE, Sloley BD (1991) Testosterone and estradiol potentiate the serum gonadotropin response to gonadotropin-releasing hormone in goldfish. Biol Reprod 44:951-960

Trudeau VL (1997) Neuroendocrine regulation of gonadotrophin II release and gonadal growth in the goldfish, Carassius auratus. Rev Reprod 2:55-68

U.S Fish \& Wildlife Service (2016) Fish and Aquatic Conservation. https:/www.fws.gov/fisheries/aadap/inadsavailable/spawning-aids/ovaplant-sgnrha/index.html. Cited by 07 Aug 2017

Xu J, Huang W, Zhong C, Luo D, Li S, Zhu Z, Hu W (2011) Defining global gene expression changes of the hypothalamic-pituitary-gonadal axis in female sGnRH-antisense transgenic common carp (Cyprinus carpio). PLoS One 6:e21057

Yilmaz O, Prat F, Ibáñez A, Amano H, Koksoy S, Sullivan CV (2015) Estrogen-induced yolk precursors in European sea bass, Dicentrarchus labrax: status and perspectives on multiplicity and functioning of vitellogenins. Gen Comp Endocrinol 221:16-22

Zohar Y (1989) Endocrinology and fish farming: aspects in reproduction, growth, and smoltification. Fish Physiol Biochem 7:395-405

Zohar Y, Mylonas CC (2001) Endocrine manipulations of spawning in cultured fish: from hormones to genes. Aquaculture 197:99-136 